\title{
Research on governmental malfunctions, market failure and the subjects of farmers' education
}

\author{
Chengwei Chu ${ }^{1, a}$, Qinling Jing ${ }^{2, b}$ \\ ${ }^{1}$ Editorial Department of Journal , Anqing Vocational and Technical College, Anqing, Anhui, \\ 246003, China \\ ${ }^{2}$ Faculty of Economics and Managemen,Northwest A \& F University,Yang ling, 712100,China \\ aemail: chuchenwei520@163.com, bemail: Jql_2000@163.com
}

Keywords: government failure; market failure, subjects of farmers' education; the third sector

\begin{abstract}
The promoting process of farmers' education is a dynamic process in which the two propositions of "governmental malfunctions "and "market failure " complement and play game each other. During the present process, government must be in the dominant position. At the same time, it is necessary to accurately define the rights border and functional position of government and market which can guide the market-oriented of farmers' education and make enterprises and entrepreneurs play a maximize role; develop the function of "the third sector" besides of government and market in the comprehensive reform and foster multicultural subjects which can comprehensively promote the development of farmers' education.
\end{abstract}

\section{Introduction}

It cannot be denied that the situation of farmer's education in China is different from developed countries and is also different from the general developing countries which have special background and progressive nature of reform in China. The function of government and the ability of controlling of resources of government are quite powerful. And the government takes the dominance role in farmer's education because of the path dependence on the education mode in the history of farmer's education in past.

No matter in modern society or in ancient society and in Chinese contemporary or in developed countries, the government always plays an important role in economic development and social progress. And the only difference is the environment, dynamics, way and effect of government intervention. The function of government is undoubted not only in the economic development and macro-control but also in public affairs and social public welfare undertakings. As the manager, server and coordinator of public services and facilities, the government takes an important role and acts as the leading power. Although the thought of "the limited government" based on criticizing "the government is all-purpose theory" insists that the power of government should be limited even in the field of social and public welfare undertakings and promotes mercerization reform. For example, some scholars argued that the reform process of mercerization and privatization operated in the field of public service and public welfare undertaking is also the gradual exiting process of government department. This is not only related to the maintenance and appreciation of the state-owned assets, but is also an orderly process which means that it can still ensure the healthy development of public undertakings after the government withdraw. Therefore, in a certain sense, whether the reform in public affairs is successful is closely linked with the success of government exiting. The choice of the opportunity of reform, the reform path and reform way must be according to the time, conditions and environment, and also need to find the reasonable boundaries in the interdependent between "government failure" and "market failure". 


\section{Design of the Chip Kick Mechanics The analysis of the dominance role of government in farmer's education}

Paying attention on that government plays a dominate role in farmer's education is necessary and appropriate under the special situation that the government control over the powerful recourses and the Chinese social reform has special characteristics and in the transition stage that a large scale of reform is impossible.

Firstly, we should perfect the government's financial input mechanism, make it normalization and institutionalization and make sure its execution. It is decided by the particularity of education and responsibilities that government should ensure the sufficient supply and institutionalized allocation of education funding. "Within the perspective of the government duty, citizens are the principal and the government is agent of citizens, according to the agency theory, the government has the responsibility to provide public services and facilities including education. This requires that government investment education and guarantees the ample supply of education funding”. Within the perspective of the education itself, the education benefit not only has private quality but more has social quality. The education benefit has great externality which means that the society is the greatest beneficiaries in education. The core elements of world competition are the competition of education and talents and the improving function of education for the development of society is more obvious. But education development needs the support of resources and needs a lot of funding provided by government in all countries so as to ensure the healthy development of education.

Secondly, drawing up and perfecting the relevant management and operation system in the process of farmer's education and carrying out policy innovation on this basis are the responsibility of government. The theory of property rights in Western new institutional economics considers that as long as the property is clear, market mechanism can resolve the existing economic problems in the most efficient way. The function of government is to formulate rational property rights system and other management system. However "the role of government in the institutional innovation in order to promote economic growth is not neutral, but is irreplaceable, because the government decides the structure of property right and is finally responsible to the efficiency of the property right structure which caused economic growth, decline and stagnation. Good government should make the increasing remuneration between economic organizations (enterprise) and political organization (government) consistent. Therefore, the government should draw up a reasonable property system, ensure fair competition and market rules and also make the behaving of government fit into the track of institutionalization. "In the governance structure of government in China, one of the functions of government is fully using legal resources to plan, coordinate and organize social activities. If there are no scientific, reasonable and effective system design and policy considerations, all economic and social works including farmers education will fall into a state of passive and blind.

Thirdly, the main role of government in the process of farmer education, especially in some field of farmer's education, cannot be ignored and its function orientation should be clearer. Influenced by the mode of western farmer's education, many scholars believed that the leading role of government should be reduced in the process of farmer's education and serve as a guide and investors. As the general trend of farmer's education reform, this kind of thought has certain scientific significance and active value guidance, especially in the field of farmer's vocational education and agricultural technology training. However, farmer's education not only means vocational education which includes farmer's ideological and political education, farmer's culture education, legal education and sports education and so on. In these fields, it is apparently recklessness to ignore the role of government, totally request the running mode according to farmer's vocational education and fully introduce market mechanism and the competition of other market participants which is totally not consistent with China's national conditions. The government in this field has the function of direction guidance, organization and implementation, capital support, standard management and feedback evaluation which is very outstanding. Even in western countries of free economy, the government is also tend to strengthen the functions of government and exert 
its maximization of utility in these field related to social welfare, public welfare and national cultural quality.

\section{Institutions Optimization Design Faemer's education in "government failure" and "market failure"}

In the system of modern market economy, market regulation and government intervention, and free competition and macro-control are closely linked, mutually intertwined and are important indispensable components. Because the completely effectiveness of market mechanism exists only under the condition of strict hypothesis and the perfection of government intervention is also just linked with "ideal government". That is to say, market regulation and government intervention are not everything which both have intrinsic defects and objective possibility of failure.

Within the perspective of the process of farmer's education, the role of government is also not everything in which exists the phenomenon of "government failure", such as the process of farmer's education policy evolve and modification of government also illustrates the policy of farmer's education has deviation in a certain degree and the low efficiency of the administrative agencies is also a well-known fact in China; And the powerful ability of government to dominate resources often leads to the rights offside and abuse of government in the process of farmer's education. In the process of farmer's education in China, the phenomenon of "market failure" also exist in a certain scope because of the powerful position of current government. Therefore, in the process of future education reform, the influence of negative factors in the market orientation must be paid more attention and try to minimize the influence.

Starting from weighting the limitation of government function and the inherent ills of market regulating mechanism, the promoting process of farmer's education is actually a mutual complementation and game dynamic process between "market failure" and "government failure". The government management has a quality of compulsory plan and allocation which can't achieve the optimal allocation of resources and the effect of "praetor optimality" under market economy. Especially in present situation that liberal is popular, the function of the government is required to be restricted whose ills is obvious; but, as an element having great system benefits, the market function is also not everything. However it is like a counter argues that "market failure" is caused by government regulation, the scope of market failure is the scope of government regulation which means that the market failure is associated with the government regulation. When the phenomena of market failure appear, the government corrects and improves the defects of market mechanism and intervene resource allocation through regulation so as to achieve the purpose of government management.

In order to seek the best junction between the market mechanism and government regulation of economic and social development, the key is to fully understand the inherent defects of government and market, at the same time analyze the unique government management system and the operation characteristics of " Chinese economy system of socialism market ", accurately define the right boundary and functional position of government and market, develop the "third-department" function besides government and market in synthetically reform and thereby promote farmer's education more effectively. Because Chinese socialist market economy does not take a pure laissez-faire market economy as a starting point, but transit into a market economy based on a highly centralized plan economy. Therefore the trace and characteristics of government leading are unavoidably reflected in this process. Even because of the lack of thoroughness social transformation, the government function still play a leading role in certain time and the role of government is still a kind of rational orientation and the boundary between government and market is not clear. Meanwhile due to the uncertainty of boundary standard and the difficult of partitioning method, it is difficult to make sure this boundary to fully achieve precise in practice which also caused function confusion. "The reform of government management system and government function conversion is necessary. I think the problem faced by China now is: the problem and missing faced by China in the aspects of public management, public services, income transfer payment aspects and so on should be resolved through the reform of government management 
system and the more long-term political system reform" In synthetically coordination aspects of reform, we should actively develop the function of "the third-department" besides government and market. Generally speaking, "when the cost that the government and market works individually and works together is constantly greater than the benefits (or efficiency, or eventually social welfare), the government and market are in a state of common failure. The common failure of government and market is also caused by itself existed natural defects which is difficult to overcome. Therefore only the 'the third sector' of non-governmental and non-market can play a role in this area”.

\section{Conclusion}

To sum up, because the particularity of the transformation of Chinese society and the progressive of social reform, we must ensure the leading position of government in the current promoting process in the process of farmer education; Meanwhile, exactly define the rights boundary and positioning function of government and market, guidance the market-oriented management of farmer's education and make enterprises and entrepreneurs play the role in greatest degree; develop the function of the "third-department" besides the government and market in the comprehensive reform, cultivate diverse education subject, and promote the development of farmer's education.

\section{Acknowledgement}

When it comes to the acknowledgment, I want to give many thanks to all that helped me. I want to give my heartfelt thanks to this study "The cooperative personnel training base about landscape plants between agriculture, science and education” (2012sjjd055). To sum up, thank you all for all your consideration!

\section{References}

[1] Jianhe Teng, exerting the function of government to promote the realization of social education fairness, Pioneering With Science and Technology Monthly, 2006(6): 166

[2] North, Douglass C., 1990a, Institutions, Institutional Change and Economic Performance, Cambridge University Press, 1990.

[3] Zhigang Wang, Discussing of government regulation, Science and technology information 2008 (17) : 162

[4] Sui Xi, To overcome the government failure of modern economic society, Jiangsu countryside economic 2008 (12) : 66

[5] Zhang yan, the reasonable boundaries of government function under the transformation system, Economic BBS 2007 (12) : 5

[6] Zhenglai Deng, State and Civil Society, Central Compilation \& Translation Press, 1999:8 